Meta

Journal des traducteurs

Translators' Journal

\title{
A Comparative Analysis of Korean-English Phonological Structures and Processes for Pronunciation Pedagogy in Interpretation Training
}

\section{Junmo Cho et Hae-Kyeong Park}

Volume 51, numéro 2, juin 2006

Théories et pratiques de la traduction et de l'interprétation en Corée Theories and Practices of Translation and Interpretation in Korea

URI : https://id.erudit.org/iderudit/013253ar

DOI : https://doi.org/10.7202/013253ar

Aller au sommaire du numéro

Éditeur(s)

Les Presses de l'Université de Montréal

ISSN

0026-0452 (imprimé)

1492-1421 (numérique)

Découvrir la revue

Citer cet article

Cho, J. \& Park, H.-K. (2006). A Comparative Analysis of Korean-English Phonological Structures and Processes for Pronunciation Pedagogy in Interpretation Training. Meta, 51(2), 229-246. https://doi.org/10.7202/013253ar
Résumé de l'article

Cet article a pour but d'analyser l'enseignement de la prononciation en langue B (la langue de travail). L'article fait une analyse comparative des structures et des processus phonologiques du coréen et de l'anglais, et propose des suggestions pédagogiques. L'étude conclut qu'avec la connaissance appropriée des structures et des processus phonétiques/phonologiques, ainsi qu'avec l'enseignement et les exercices adéquats, les étudiants coréens en interprétation peuvent améliorer leur qualité d'interprétation vers l'anglais. 


\title{
A Comparative Analysis of Korean-English Phonological Structures and Processes for Pronunciation Pedagogy in Interpretation Training
}

\author{
JUNMO CHO \\ Handong Global University, Pohang, Korea \\ junmocho@handong.edu
}

HAE-KYEONG PARK

Handong Global University, Pohang, Korea becky@handong.edu

\section{RÉSUMÉ}

Cet article a pour but d'analyser l'enseignement de la prononciation en langue B (la langue de travail). L'article fait une analyse comparative des structures et des processus phonologiques du coréen et de l'anglais, et propose des suggestions pédagogiques. L'étude conclut qu'avec la connaissance appropriée des structures et des processus phonétiques/phonologiques, ainsi qu'avec l'enseignement et les exercices adéquats, les étudiants coréens en interprétation peuvent améliorer leur qualité d'interprétation vers l'anglais.

\section{ABSTRACT}

This paper discusses the rationale for providing pronunciation training in $B$ language to students of interpretation working into B. It also provides a thorough comparative analysis of Korean-English phonological structures and processes followed by pedagogical suggestions for instructors of interpretation. This study concludes that with the proper knowledge on the contrastive analyses of phonetic/phonological structures and processes and with proper instruction and practice, Korean students of interpretation will acquire better speech delivery and interpretation quality into English.

\section{초록}

본 논문은 $\mathrm{AB}$ 통역이 필연적으로 요구되고 있는 한국 통역 현장의 특수성에 기인 하여 국내의 통역 교육을 담당하는 기관의 교육과정 중에 B 언어로의 통역을 위한 발음 훈련이 포함되어야 하는 당위성을 제시한다. 보다 구체적으로는, 한영 통역을 위한 한국어와 영어의 음성, 음운체계 및 음운 법칙에 관한 포괄적인 분석을 제공 하고, 그에 따른 통역훈련을 위한 발음 교수법을 제안한다. 두 언어의 음성, 음운 체 계와 그 법칙에 대한 체계적 비교 분석에 근거한 실제적 발음 교수법은 한영 통역 을 훈련함에 있어서 통역 훈련생들로 하여금 보다 더 질 높은 통역과 발화능력을 갖추게 할 것으로 판단된다.

\section{MOTS-CLÉS/KEYWORDS}

pronunciation, pedagogy, phonetic analyses, transfer of phonological processes, KoreanEnglish interpretation training 


\section{Introduction}

The AIIC Professional Standards offer the implicit message that interpreters must always interpret into their A languages, but not into their B languages. Therefore, most training institutions based in European countries see to it that they provide interpretation training from B language into A. Seleskovitch and Lederer (1989) argue that simultaneous interpretation should only be taught into trainees' mother tongues. In particular, Seleskovitch (1999) is known to adhere to the position that simultaneous interpretation into B languages must be avoided.

However, Lim (2003) criticizes such a position by pointing out that it is a luxury that only European or Western interpreters may enjoy. She asserts that "the situation in Asia...interpreting into B may be acceptable, and in fact, it is taking place almost every day of the year without any problems." Choi (2004) also argues that "[the AIIC] definitions cannot always be applied in the same manner with Korean conference interpreters because they regularly have to work not only into their A language but also into their B language or retour language because there aren't any foreign interpreters who can interpret into Korean." In her survey study on the competitiveness of interpretation into B, 91.3\% of Korean-English interpreters who have more than two years of field experience answered that they work into both Korean and English equally. She emphasized that Korean interpreters must have nearly as much proficiency in their B language as their A language.

Korean interpreters must have a strong 'B' language in order to meet the demands of the market. Moreover, since the Korean-English combination is the highest in demand, with many qualified interpreters honing their skills every day during peak seasons, interpreters cannot live up to the expectations of their clients with just average 'B' language skills (Choi, 2004).

In this respect, Déjean Le Féal (2003) argues that due to the fact that minor languages are not taught in interpretation schools outside the country, it is inevitable for interpretation institutions in countries of minor languages to admit applicants with a minor language as their A language and train them rigorously in their B language so that they can meet the required level of the market. This also means that interpreters should be trained to satisfy their B language audience expectations.

Research on audience expectations and preferences identified several common criteria for "good quality interpretation" though expectations and preferences differ depending on who the receiver may be. Kurz (1994) selected eight criteria: native accent, pleasant voice, fluency, logical cohesion, sense consistency, completeness, correct usage of grammar, and correct terminology. It is also suggested that intonation, pronunciation, and accent constitute naturalness of interpretation $(\mathrm{Ng}, 1992$; Shlesinger, 1994). Park (2003) also asserts that interpreters are required to be equipped with perfect language ability as well as overall speech delivery skills including diction such as phrasing, intonation, voicing, speed, and pronunciation.

Burnaby (1989) argues that "the curriculum content and learning experiences to take place in class should be negotiated between learners, teacher and coordinator at the beginning of the project and renegotiated regularly during the project." Li (2002) supports this by emphasizing that training institutions should cater to students' needs for more language training. The needs of English language training for Korean students must be taken into consideration in designing curriculum because many Korean 
students of interpretation must still pursue the parallel acquisition of language ability and interpretation skills (Park, 1999; 2004).

Among various needs of English language training for Korean students of interpretation, the focus of this paper will be given to the needs of pronunciation training. Since the highest demand in Korea is in Korean-English interpreters who regularly have to interpret into English, their English pronunciation needs to be trained for near perfection. However, there seems to be a marked lack of prior research on comparative analysis of phonetic and phonological structures between Korean and English for pedagogical purposes to improve students' pronunciation.

The main purpose of this paper, therefore, is to provide a theoretical foundation for identifying Korean students' common errors in English pronunciation and thus to share the insight with instructors of Korean-English trainees at interpretation training institutions that pronunciation training of English should be included in its curriculum.

In this context, this paper attempts 1) to discuss the rationale for providing pronunciation training to Korean students of interpretation; 2) to provide a thorough comparative analysis of Korean-English phonological structures and processes; 3 ) to offer pedagogical suggestions for instructors of interpretation.

\section{Rationale for Pronunciation Training and Pedagogy}

Déjean Le Féal (1999) asserts that "in order to prepare the students for their future professional careers, the programme will include elements such as communication skills, e.g. voice coaching, public speaking, etc."

Minns (2002), from his twenty-five years of teaching experience in interpretation into $\mathrm{B}$, summarizes nine strategies that he thought were necessary for students interpreting into B. He stresses the importance of pronunciation training that there should be allocation of teaching time devoted to exclusively linguistic aspects of pronunciation of students' B language.

Korean and Vietnamese students however almost invariably need intensive coaching and/or practice in the production of sound and intonation patterns in English (Minns, 2002).

Kondo (2003) shares a similar observation from his interpretation class.

Recently in my interpreting class a Japanese student was shocked to find that the Chinese students in the class could not repeat some very simple English sentences he uttered... Since English is spoken by many different groups, we must get used to different accents but also we must train our students to speak in such a way that would be understood easily by all other linguistic and ethnic groups (Kondo, 2003).

When engaged in the actual task of pronunciation training, the first thing that comes to one's mind would be to identify pronunciation errors. One needs to know exactly which errors are made in order to correct them. At this point, what many instructors may hurriedly do is to simply provide a correct pronunciation of the erred counterparts and instruct the students to mimic them until they succeed. But many instructors would agree that although certain errors are easily corrected with minimal effort, other errors are almost impossible to correct. Pronunciation teaching attempts may then well be a source of an unpleasant, if not absolutely frustrating, experience for both students and instructors. 
In their study on teaching pronunciation, Celce-Murcia and Goodwin (1991) note the importance of moving beyond the simple identification of mistakes for some students.

For a course focusing on pronunciation at a more advanced level, it is useful to present a diagram of the organs of speech, the phonetic alphabet, the consonant chart, and the vowel chart [...] The organs of speech diagram illustrates the place of articulation for both consonants and vowels, and although not all students or sounds respond well to such articulatory explanation, it can be quite productive for others. In addition to place of articulation, the consonant chart allows us to address the manner of articulation and voicing [...] the vowel chart is an aid in differentiating the sounds [...] (Celce-Murcia and Goodwin, 1991).

Therefore, one needs to proceed to ask why pronunciation errors are made in the first place. When considering this question, it is soon noted that most pronunciation errors are particular, not random. Furthermore, pronunciation mistakes by interpreters of a specific A language while targeting a specific B language are idiosyncratic to that of A language speakers. For instance, it is quite common to find that Korean students of interpretation make pronunciation mistakes in English that are unique to Koreans.

The obvious reason is that the sounds available, and therefore used with ease, in Korean are unique to Korean. The pronunciation mistakes arise from the differences in the kinds of sounds in Korean and those of English. For instance, the [f] sound in English is hard for Korean interpreters simply because Korean does not have such a sound.

There are also less expected, thus easily ignored, reasons for the uniqueness of pronunciation errors. First, certain pronunciation errors are due to the differences in phonotactics - combinations of sounds permitted in a particular language - between Korean and English. Secondly, Korean-particular mistakes are made due to the 'transfer' of certain aspects of the Korean phonological processes into English. Lastly, those idiosyncratic mistakes are made due to the failure to acquire certain phonological processes in the English language.

Knowledge of the specific phonetic/phonological reasons for pronunciation errors is very valuable if instructors are serious about helping students improve their pronunciation. Such knowledge will provide them guidance not only as to where to focus their teaching but also in how to help them from a well-established theoretical foundation. Consequently, it is vital that instructors engage in cross-linguistic phonetic/phonological analyses of the native and target languages of interpreters as a basis for developing pronunciation-training methodologies.

In the following sections, theoretical reasons for pronunciation errors made by Korean students while interpreting into English are presented. In particular, a comparative analysis of phonetic and phonological structures of Korean and English in the spirit of Contrastive Analysis Hypothesis (Lado 1957; Wardhaugh 1970) is provided.

\section{Comparison in Phonemic Inventories}

The first area of comparison concerns the most basic differences of the two languages, namely, the availability of sounds. Phonemic inventory ${ }^{1}$ of each language is unique. 
Therefore, not all sounds of A language are necessarily available in B language, and vice versa. Although it is quite easy to recognize such differences in the languages being compared, often such recognition is rather superficial. A detailed study of the phonemic inventories reveals a more thorough comparison of the sounds available in the two languages, and more often than not such a comparison helps us realize some unexpected sounds or groups of sounds that deserve more attention for training than others.

\subsection{Vowels}

\subsubsection{Vowel Inventories}

When one compares and contrasts sounds of any given two languages at a superficial level, one usually pays more attention to consonants than vowels, perhaps due to the acoustic prominence of consonants in relation to vowels. However, a close examination of vowel systems of English and Korean reveals that in reality more attention is needed for vowel contrasts than for consonants. Observe (1) below which represents an inventory of Korean simple vowels.

1) Korean Phonemic Vowels

\begin{tabular}{|cccc|}
\hline I & u & u \\
& & v & o \\
$\varepsilon$ & & & \\
& a & & \\
\hline
\end{tabular}

In the Korean vowel system, we have two front unrounded vowels; one is high and the other is non-high: /I/ and / $\varepsilon /$ respectively. There is one non-front (either mid or back) low vowel /a/. Two rounded vowels are found in high back position and mid back position: /u/ and /o/ respectively. Korean also has two unrounded vowels that are generally uncommon in other languages, namely the high back unrounded vowel /w/, which in fact often ranges from central to back, and the mid back unrounded vowel $/ \mathrm{\gamma} /$. Lastly, Korean has ten diphthongs all of which are combinations of a glide and a vowel: /ja/, /jy/, /jo/, /ju/, /je/, /wa/, /wr/, /we/, /wi/, /uil/. Now observe (2), the English Phonemic Vowel Chart. ${ }^{2}$

2) English Phonemic Vowels (adopted from O'Grady and Archibald 2004)

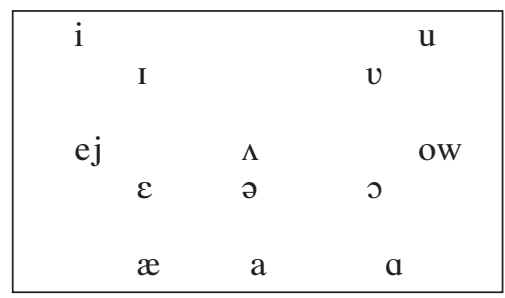

English phonemic vowels include a lot more fine-grained distinctions, compared to those of Korean. First of all, both high front and high back regions have two different vowels separated by the tense/lax distinction. Thus, although both are unrounded, high and front, $/ \mathrm{i}$ / is distinguished from $/ \mathrm{I} /$ in that the former is a tense version of the latter, as exemplified in the minimal pairs ${ }^{3}$ such as 'beat' vs. 'bit.' In the same way, /u/ 
is the tense version of the lax counterpart / $/$. Examples of the contrast can be found in pairs such as 'pool' vs. 'pull.' By the same token, mid front and mid back vowels have the tense and lax distinction. There are two mid front unrounded vowels, /ej/ as in 'bait' and $/ \varepsilon /$ as in 'bet,' the former being tense and the latter lax. There are also two mid back rounded vowels, /ow/ as in 'boat' and / / 'as in 'bore,' where the former is tense and the latter also lax. But, note that the tense/lax distinction is not the only distinguishing factor for the mid front and mid back vowels in English. The tense versions of the mid front and mid back vowels in English are all diphthongized. That is, /ej/ is not like a simple /e/ nor is /ow/ like /o/. ${ }^{4}$

The mid central vowels in English have both $/ \Lambda /$ as in 'butt' and schwa $/ \partial /$ as in the second syllable of 'Rosa.' The occurrences of the two mid central vowels are usually distinguished by the presence or absence of stress. The front low vowel /æ/ is found in such words as 'bat,' and the low back vowel /a/ in such words as 'pot.' The low central vowel /a/ is quite rare and it usually occurs only as the first part of diphthongs. As for diphthongs, the English diphthongs are uniformly composed of the sequence of a vowel and a glide, exactly the opposite sequence from that of Korean. Besides /ej/ and /ow/, there are /aj/ as in 'sigh,' /aw/ as in 'how' and /oj/ as in 'joy.' Also, some phoneticians note that the high front and back unrounded tense vowels are slightly diphthongized. Thus, they transcribe them as /ij/ and /uw/.

\subsubsection{Error Analysis}

In this section, we undertake a fine-grained comparison between the two languages' vowel systems in order to account for the actual pronunciation errors commonly attested. First of all, we note that Korean has some simple vowels that are not available in English. These are summarized as below:

3) $/ \mathrm{w} / / \mathrm{O} / / \mathrm{\gamma} /$

(3) implies that these particular vowels would pose difficulty for the native speakers of English learning Korean.

More notably, however, we observe that there are many more vowels that are available in English but not in Korean. This suggests that it is much more challenging for Koreans to acquire English vowels than for English speakers to acquire Korean vowels. The English simple vowels (with the addition of two diphthongs derived from simple vowels: see endnote ii.) that are not available in Korean are summed up as below.

4) $/ \mathrm{i} / / \mathrm{v} / / \mathrm{a} / / \mathrm{ej} / / \mathrm{ow} / / \mathrm{o} / / \mathrm{a} / / \mathrm{\Lambda} / / \mathrm{a} /$

The identification in (4) likewise helps us realize that, when Korean interpreters pronounce English vowels, they will make mistakes more likely with these particular vowels than others. It goes without saying that such an identification process through an actual comparison of vowel inventories helps us greatly in designing a strategic curriculum for pronunciation improvement. Now, we can examine (4) more closely in order to identify the exact nature of the actual pronunciation errors that are commonly made by Korean speakers of English.

First, as noted above, the contrast, /ع/ vs. /æ/, in the front non-high tongue position is not found in Korean. The non-high counterpart of the front vowel in Korean, although transcribed as $/ \varepsilon /$ for lack of better notation, in fact ranges over the mid 
front and low front tongue positions. The lack of such distinction in Korean makes it challenging for Koreans to distinguish these two English vowels both in comprehension and production. Some of the minimal pairs distinguished by these vowels, thus pose special difficulty for Koreans, are shown below.

5) $/ \varepsilon /$ vs. /æ/ minimal pairs

bet, bat

set, sat

fed, fad

pen, pan

For instance, Korean students reportedly struggle in both comprehension and production with the distinction between sentences such as That's a good bet vs. That's a good bat; I set him up vs. I sat him up; This pen is expensive vs. This pan is expensive.

The /a/ vs. /a/ contrast in English is not found in Korean, either. However, this distinction poses less difficulty since the low central vowel [a] is quite rare in actual usage, and when it is used, it occurs only as the first part of diphthongs.

Second, English vowels show the tense/lax contrasts in high tongue position, namely /i/ vs./I/ and /u/ vs. /v/ contrasts which Korean lacks. Note that Korean has only one high front unrounded vowel. Although transcribed as /I/ for lack of a better symbol, it in fact ranges over the whole high front area. The same goes for the high back rounded vowel in Korean, which although transcribed as $/ \mathrm{u} /$, ranges over the whole high back area. This means Korean interpreters are predicted to have difficulty recognizing the following minimal pairs in (6) and (7).

6) /i/ vs. /I/ minimal pairs

beat vs. bit

eat vs. it

seat vs. sit

leave vs. live

scene vs. sin

keen vs. kin

7) $/ \mathrm{u} / \mathrm{vs}$. $/ \mathrm{v} / \mathrm{minimal}$ pairs

pool vs. pull

fool vs. full

Consequently, it is common to find actual production mistakes in sentences such as: Please have a seat where the last word is usually incorrectly pronounced as something close to sit, That's a beautiful scene with the last word incorrectly replaced by sin, creating a rather humorous interpretation, and I am full where full cannot be distinguished from the pronunciation of fool.

In addition to the tense/lax distinction, the high vowels in English are also distinguished by their length difference. The tense vowels are by nature longer in length than their lax counterparts. Therefore, at least in comprehension, Korean interpreters can tune into their length distinction in order to distinguish these two sets of vowels. Unfortunately, however, many Korean interpreters tend to assume that the length distinction is the only difference between these vowels in English. ${ }^{5}$ This impedes the improvement of the actual production of these vowels.

Unlike high vowels, the tense/lax distinction of the mid vowels such as /ej/ vs. / $/$ / and /ow/ vs. /o/ does not impose as much difficulty as the high vowels for Koreans 
since the tense counterparts are necessarily diphthongized in English. The off-glides of the mid tense vowels are good enough cues for Koreans to perceive the distinction easily in their comprehension.

Third, although it is quite possible for the Koreans to tune into the off-glides of /ow/ and /ej/ in order to distinguish these from their lax counterparts, the production of these vowels is of different matter. In fact, it is a challenge for the Koreans to achieve the level of production accuracy needed for successful communication. Note that the mid back rounded vowel /o/ in Korean is the closest counterpart to /ow/ in English (see (2) above). As in the case with /o/, the mid front unrounded vowel in the Korean vowel inventory is not diphthongized either, unlike the English /ej/. This difference presents itself difficult for Koreans. For instance, we find that there are common mistakes such as (8) and (9).

8) The first vowel in 'open' 'only' 'soul' 'so' often incorrectly pronounced with /o/

9) The first vowel in 'angel,' 'save,' 'pain' often incorrectly pronounced with / $\varepsilon$ /

Fourth, not only in the case with /ej/ and /ow/, but English diphthongs in general pose problems for Korean interpreters. Above, we noted that Korean diphthongs are uniformly the sequence of a glide and a vowel while English diphthongs are composed of the exact opposite sequence. Accordingly, the concept of an English diphthong is hard for Koreans to perceive. As a result, Koreans perceive English diphthongs in (10) as two independent syllables and produce them as such.

10) /aj/ side, light, kind, height, hike, like, nice

law/ sound, pound, out, cow

/oj/ boy, soy

slightly diphthongal

/ij/ me (e.g., see vs. seeing, be vs. beeing)

/uw/ moo

Fifth, due to the lack of the exact counterpart to the mid back rounded vowel / $/$, Koreans tend to replace /o/ with /o/ as exemplified in (11).

11) 'ball,' 'hall' mistakenly pronounced with $/ \mathrm{o} /$

Sixth, due to the absence of mid central vowels in Korean, Koreans tend to mistakenly replace mid central vowels $/ \Lambda$ and / / / in English with the mid back vowel / $\mathrm{\gamma} /$ or the high central unrounded vowel $/ \dot{i} /$, the closest counterparts in the Korean vowel inventory.

12) [ə] replaced by $[\mathrm{r}]$ in words such as 'ago, 'fir,' 'ferrn,' 'occcur,' 'serverer'

13) [ə] replaced by $[\mathrm{u}]$ in words such as 'open,' 'cancell'

14) $[\Lambda]$ replaced by $[\mathrm{\gamma}]$ in words such as 'butt,' 'cut' 


\subsection{Consonants}

\subsubsection{Consonant Inventories}

Observe the Korean phonemic consonants below.

15) Korean Phonemic Consonants

\begin{tabular}{|l|l|l|l|l|l|l|l|l|l|}
\hline & Bilabial & $\begin{array}{l}\text { Labio- } \\
\text { dental }\end{array}$ & Dental & Alveolar & $\begin{array}{l}\text { Palato- } \\
\text { alveolar }\end{array}$ & Palatal & Velar & $\begin{array}{l}\text { Labio- } \\
\text { velar }\end{array}$ & Glottal \\
\hline Stop & $\mathrm{p} \mathrm{p}^{\mathrm{h}} \mathrm{p}^{\prime}$ & & & $\mathrm{t} \mathrm{th} \mathrm{t}^{\prime}$ & & & $\mathrm{k} \mathrm{k} \mathrm{k}^{\mathrm{h}}$ & & \\
\hline Fricative & & & & $\mathrm{s} \mathrm{s}$ & & & & & $\mathrm{h}$ \\
\hline Affricate & & & & & $\mathrm{t} \int \mathrm{t} \mathrm{h}^{\mathrm{h}} \mathrm{t} \jmath^{\prime}$ & & & & \\
\hline Nasal & $\mathrm{m}$ & & & $\mathrm{n}$ & & & $\mathrm{n}$ & & \\
\hline Approximant & & & & & & $\mathrm{j}$ & $\mathrm{ul}$ & $\mathrm{w}$ & \\
\hline Flap & & & & $\mathrm{r}$ & & & & & \\
\hline
\end{tabular}

There are four aspects of the inventory that we want to pay special attention to. First, Korean does not have voiced obstruents. All stops, fricatives and affricates are voiceless. They do not have voiced consonants, at least in the phonemic level. Second, for most obstruents, instead of the voicing contrast, there are other contrasts at phonemic level, namely, aspiration contrast and glottis constriction contrast. Third, Korean has a flap $[\mathbf{r}]$, but no [1] or $[\mathbf{I}]$. Fourth, the number of fricatives is significantly small.

Observe the inventory of English phonemic consonants below.

16) English Phonemic Consonants (adopted from O'Grady and Archibald 2004)

\begin{tabular}{|l|l|l|l|l|l|l|l|l|l|}
\hline & Bilabial & $\begin{array}{l}\text { Labio- } \\
\text { dental }\end{array}$ & Dental & Alveolar & $\begin{array}{l}\text { Palato- } \\
\text { alveolar }\end{array}$ & Palatal & Velar & $\begin{array}{l}\text { Labio- } \\
\text { velar }\end{array}$ & Glottal \\
\hline Stop & $\mathrm{p} \mathrm{b}$ & & & $\mathrm{t} \mathrm{d}$ & & & $\mathrm{kg}$ & & $?$ \\
\hline Fricative & & $\mathrm{f} \mathrm{v}$ & $\theta \partial$ & $\mathrm{s} \mathrm{z}$ & $\int 3$ & & & & $\mathrm{~h}$ \\
\hline Affricate & & & & & $\mathrm{t} \int \mathrm{d} 3$ & & & & \\
\hline Nasal & $\mathrm{m}$ & & & $\mathrm{n}$ & & & $\mathrm{n}$ & & \\
\hline Approximant & & & & $\mathrm{l}$ & & $\mathrm{j}$ & & $\mathrm{w}$ & \\
\hline
\end{tabular}

By contrast, we find that all obstruents in English, besides the ones produced at glottis, have voiced/voiceless counterparts. We also note that there are many fricatives in a variety of places of articulation.

\subsubsection{Error Analysis}

Based upon the fine-grained comparison of the consonant inventories of the two languages, we now explicate the actual errors in pronunciation. (17) is the summary of Korean consonants that do not exist in English.

17) $/ \mathrm{p}^{\mathrm{h}} / / \mathrm{p} / / \mathrm{th} / / \mathrm{th} / / \mathrm{k} \mathrm{h} / / \mathrm{k}^{\prime} / / \mathrm{s} / / \mathrm{t} \int \mathrm{h} / / \mathrm{t} \mathrm{f}^{\prime} / / \mathrm{s} /$

(17) implies that this set of consonants will pose problems for English speakers learning Korean. Most notably the obstruents with constricted glottis will be the hardest to acquire.

(18) is the list of English consonants not found in Korean.

18) $/ \mathrm{b} / / \mathrm{d} / / \mathrm{g} / / \mathrm{f} / / \mathrm{v} / / \theta / / \mathrm{d} / / \mathrm{z} / / \mathrm{g} / / \mathrm{z} / / \mathrm{d}_{3} / / \mathrm{l} / / \mathrm{d} /$

(18) helps us to identify four major areas of pronunciation errors. 
First, although consonants such as $/ \mathrm{b} / / \mathrm{d} / \mathrm{g} / / \mathrm{d} 3 /$ are commonly found crosslinguistically, these consonants are not found phonemically in Korean. Korean, on the other hand, employs a voicing process: voiceless consonants become voiced between voiced segments. Thus, the English voiced consonants that are not between voiced segments are hard to pronounce for Koreans. Generally, the voice onset time (the time at which vocal chords begin to vibrate) for such consonants tends to be quite late for Korean speakers. (19) shows some attested mistakes.

19) a. The first consonant of 'John' often mistakenly pronounced with the unaspirated voiceless counterpart $/ \mathrm{t} \mathrm{J} /$

b. The first consonant of 'Bob' often mistakenly pronounced with the unaspirated voiceless counterpart /p/

Second, due to the absence of fricatives such as $/ \mathrm{f} / / \mathrm{v} / / \theta / / \mathrm{d} / \mathrm{z} / / \mathrm{J} / / 3 /$, many errors are made with these sounds. Most errors are made replacing such fricatives with nearby stops or affricates as shown in (20).

20) Common replacement errors
a. /f/ in 'fine' by /p/
b. /v/ in 'vine' by /b/
c. $/ \theta /$ in 'three' by $/ \mathrm{s} /$
d. /ð/ in 'there' by /d/
e. $/ \mathrm{z} /$ in 'zebra' by $/ \mathrm{t} \mathrm{j} /$
f. $/ 3 /$ in 'measure' by $/ \mathrm{t} \mathrm{f} /$

Third, the absence of / / and / $/ \mathrm{/} /$ in Korean causes one of the most easily recognized errors. The contrast between these two liquids poses a problem for such distinctions as (21).

\section{1) 'lice' vs. 'rice'}

Both 'lice' and 'rice' are commonly pronounced replacing /l/ and / $/$ / with the Korean flap / $/$. What makes it worse is that Koreans tend to associate / $/$ / with English /l/ rather than with / I/, possibly due to a phonological process that turns / $\mathrm{I} /$ into /l/ under a particular phonological environment, which we will discuss below. This goes against a common expectation of English speakers. Most English speakers, upon hearing a second language speaker pronouncing a flap such as $/ \mathrm{r} /$, assume that she is imitating an English / $\mathrm{I} /$ rather than /l/. After all, English / $\mathrm{I} /$ is a notorious sound for many second language speakers and many speakers from different language backgrounds would mimic this with various trills and flaps. Consequently, words such as 'row' pronounced with $/ \mathrm{r} /$ are easier for English speakers to comprehend than words such as 'low' pronounced with $/ \mathrm{r} /$. This is exactly opposite to Korean speakers' expectation. Koreans, instead of concentrating their pronunciation skills on $/ 1 /$, which is more urgent, unfortunately focus solely upon $/ \mathrm{x} /$.

Fourth, English consonants in (22) are inherently rounded: these consonants are always pronounced with the rounding of lips. ${ }^{6}$ Since these consonants are inherently rounded, most transcription practices do not bother to mark the rounding with a superscript such as $/ \mathrm{I}^{\mathrm{w}} /$. 
22) Inherently rounded consonants: / $\mathrm{d} / \mathrm{J} / / \mathrm{z} / / \mathrm{t} / / \mathrm{d} 3 /$

Because of the absence of such a marking, speakers of a language where such consonants as (22) are unrounded are misled. It is common that Korean interpreters substitute these consonants with unrounded counterparts. For instance, even when Koreans approximated the pronunciation of $/ \mathrm{I} /$ and $/ \mathrm{J} / \mathrm{as}$ in 'rat' and 'sheep' to a high degree of success, they still tend to pronounce these segments without the rounding of lips.

\subsection{Suprasegmentals}

The stress (pitch/accent) system in modern Korean, if it exists at all, plays a small role at the lexical level. Most lexical items' meanings are not distinguished by the presence or absence of a stress, for example. Such is contrary to the status of stress in English, as illustrated in (23) below.

23) To build the road, we'll need a new survey.

This is the site we need to survey.

The modern Korean does not employ length distinction of vowels for lexical distinction either. Consequently, Koreans tend to treat the stress patterns and vowel length distinctions in English as something additional not as something crucial for the meaning of lexical items. In their production of English words, they do not pay attention to, or completely ignore, the stress patterns and vowel length distinction. This lack of attention often reduces the communicability of Koreans speaking English.

\section{Comparison in Phonotactics}

As (24) indicates, there is a striking difference between Korean and English in the number of constants allowed in both onset and coda position of syllables.

24) Maximal syllable structure in Korean: $\mathrm{CVC}(\mathrm{C})$

Maximal syllable structure in English: CCCVCCC

Whereas Korean allows a maximum of one consonant in the onset position, English permits up to three consonants. The same goes for the coda position consonants: Korean allows one consonant and in very rare instances, two (restricted to a few combinations) whereas English permits up to three consonants. This drastic difference leads to several syllable structure preservation tactics that Koreans employ when they deal with English syllable structures which obviously remain outside the domain of a legitimate syllable structure represented in their minds. We will examine these 'tactics' in detail in section 5.

In addition to the striking difference between the general syllable structures of the two languages, there are other constraints in Korean syllables on account of which Korean speakers have a hard time mastering English pronunciation.

First, Korean does not allow fricatives in coda position. What is phonemically a fricative or an affricate in a coda position becomes a stop via a phonological process, to which we will turn in section 5. In contrast, English freely permits fricatives in coda position. As a result, the final fricatives and affricates in words such as (25) cause difficulty for Koreans. These fricatives are either replaced by stops and/or followed with an inserted default vowel to make it non-final in a syllable. 


$\begin{array}{lll}\text { 25) a. } & \text { Steve } & {[\mathrm{v}]} \\ \text { b. } & \text { has } & {[\mathrm{z}]} \\ \text { c. } & \text { half } & {[\mathrm{f}]} \\ \text { d. } & \text { garage } & {[3]} \\ \text { e. } & \text { peace } & {[\mathrm{s}]} \\ \text { f. } & \text { hash } & {\left[\int\right]}\end{array}$

Secondly, English allows certain consonant + vowel combinations which Korean does not. The following is a set of commonly recognized combinations that are problematic for Korean speakers.

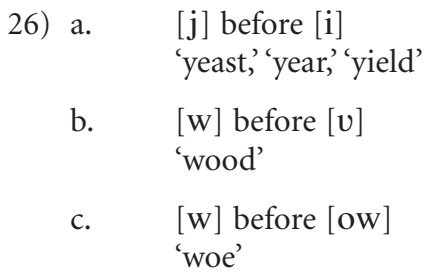

When trying to pronounce such words as in (26), Koreans tend to completely drop $[\mathrm{j}]$ and $[\mathrm{w}]$ before these vowels. Thus, they end up failing to distinguish the contrasts such as 'yeast' vs. 'east,' and 'year' vs. 'ear.' In many cases, it is hard for Koreans to even grasp that these words should contrast. The lack of such knowledge is well reflected in the incorrect pronunciation of 'the' as [ðI] in front of 'year' and 'wool.'

\section{Comparison of Phonological Processes}

In addition to the differences in phonemic inventories discussed in section 3 and phonotactics discussed in section 4 , we finally move on to the discussion of phonological processes in this section.

In contrast to phonemic inventories and even phonotactics, phonological processes of a given language are unknown to its speakers at a conscious level. Consequently, the influence of phonological processes remains at the subconscious level. This implies that it is going to be harder to help speakers correct pronunciation errors related to phonological processes than other aforementioned reasons.

\subsection{Transfer}

Errors are made for Koreans when certain phonological processes available in Korean but not in English are unknowingly transferred over to English. In this section, we identify seven common instances of such transfers.

First, Korean has a regressive assimilation where stops become nasals of the same places of articulation in assimilation to the following sonorants.

27) Regressive assimilation in Korean

$\begin{array}{llll}\text { /kapnita/ } & \text { 'go' } & \rightarrow & {[\text { kamnita }]} \\ \text { /kathni/ } & \text { '(Are they) same?' } & \rightarrow & {[\text { kanni }]} \\ \text { /makni/ } & \text { 'Are you stopping it' } & \rightarrow & {[\text { manni }]}\end{array}$

As a result, we commonly find errors as in (28) where the underlined ' $\mathrm{t}$ ' and ' $\mathrm{p}$ ' in English also turn to $[\mathrm{n}]$ and $[\mathrm{m}]$ under the influence of $[\mathrm{m}],[\mathrm{l}]$ or $[\mathrm{j}]$. 
28) Transfer of Regressive assimilations

$\begin{array}{llll}\text { sit me } & / \mathrm{t} / & \rightarrow & {[\mathrm{n}]} \\ \text { put me } & / \mathrm{t} / & \rightarrow & {[\mathrm{n}]} \\ \text { at least } & / \mathrm{t} / & \rightarrow & {[\mathrm{n}]} \\ \text { at me } & / \mathrm{t} / & \rightarrow & {[\mathrm{n}]} \\ \text { at you } & / \mathrm{t} / & \rightarrow & {[\mathrm{n}]} \\ \text { worship you } & / \mathrm{p} / & \rightarrow & {[\mathrm{m}]}\end{array}$

Second, consonants in coda position are never released in Korean. (29) illustrates this process.

29) $/ \mathrm{mok} /$ 'neck' $\quad \rightarrow \quad\left[\mathrm{kok}^{\prime}\right]$

/pap/ 'meal' $\rightarrow$ [pap']

$/$ kot/ 'immediately' $\rightarrow \quad\left[\operatorname{kot}^{\uparrow}\right]$

Unlike Korean, however, English consonants in coda position are usually released. As a result of the transfer of this process, we observe errors in (30) where the final [p] and $[\mathrm{t}]$ are systematically pronounced without releasing.

30) stop [stap $]$

street [st.iir $\left.\mathrm{t}^{\top}\right]$

Third, as discussed earlier, English allows more consonants in both onset and coda positions than Korean does. Thus, in an effort to preserve the syllable structure as that of Korean, Korean speakers utilize epenthesis processes to break up consonant clusters whereby they incorrectly insert the default vowel /u/ to maintain their native syllable structure intact. (31) below illustrates instances of epenthesis in the onset position to preserve the Korean syllable structure where no more than one consonant in the onset of a syllable is allowed. Note that as many as three consonants in English onset position are disrupted by the default vowel resulting in simple CV syllable structure.

31) Epenthesis in onset position

$\begin{array}{ll}\text { strike } & {[\text { sutwi. }]} \\ \text { stop } & {[\text { sut }]} \\ \text { clean } & {\left[\mathrm{k}^{\mathrm{h} u l}\right]} \\ \text { speed } & {[\text { supp }]} \\ \text { true } & {\left[\mathrm{th}^{\mathrm{h}} \mathrm{u} . \mathrm{I}\right]} \\ \text { cream } & {\left[\mathrm{k}^{\mathrm{h}} \mathrm{u} . \mathrm{I}\right]} \\ \text { clean } & {\left[\mathrm{k}^{\mathrm{h}} \mathrm{u} . \mathrm{I}\right]}\end{array}$

Recall that Korean usually allows no more than one in the coda of a syllable. (32) is an illustration of epenthesis whereby two coda consonants are disrupted by the default vowel ${ }^{7}$.

32) Epenthesis in coda position

$$
\begin{aligned}
& \text { gasp [suphu] } \\
& \text { elk [luk } \left.\left.{ }^{h} u\right] \text { or [lk }{ }^{h} u\right] \\
& \text { past [suthu] }
\end{aligned}
$$

Fourth, Korean has a palatalization process whereby the alveolar obstuents such as $/ \mathrm{s} /, / \mathrm{t} /$ and $/ \mathrm{th} /$ turn to their allophones $[\mathrm{f}]\left[\mathrm{t} \int\right]$ and $\left[\mathrm{t} \int \mathrm{h}\right]$ respectively when they occur before the vowel /I/. (33) illustrates the process. 
33) Korean palatalization: $\mathrm{s}, \mathrm{t}, \mathrm{th} \rightarrow \int, \mathrm{t} \int, \mathrm{t} \int \mathrm{h} /{ }_{-} \mathrm{I}$

/sosik/'news' $\rightarrow \quad\left[\right.$ so $\left.\int \mathrm{Ik}\right]$

$/$ kath $/$ 'together' $\rightarrow \quad\left[\right.$ ka t $\left.\int \mathrm{h}_{\mathbf{I}}\right]$

This palatalization process tends to be transferred over to English. Thus, Koreans, who do not have a problem with the sound [s] generally, often mistakenly pronounce English [s] as [S] when it precedes [I]. As a result, although they do not show any difficulty with words such as 'sad,' 'sound,' 'sorry,' 'soon,' they do show difficulty with words shown in (34) below.

34) /s/ in 'sick,' 'simple,' 'sin' often mistakenly pronounced with $[\mathrm{f}]$

Fifth, there is a phonological process that changes the flap / $/$ into [1] when it occurs in coda position, as illustrated in (36) below.

36) $1 /$ r variation

$f \rightarrow 1 /$ in coda position.

$\begin{array}{llll}/ \text { khar/ } & \text { 'knife' } & \rightarrow & {[\mathrm{khal}]} \\ / \text { parmok/ } & \text { 'ankle' } & \rightarrow & {[\text { palmok }]}\end{array}$

As we briefly discussed above, Korean does not have the liquids found in English, namely / $/ \mathrm{I} /$ and $/ \mathrm{l} /$. The closest counterpart to these liquids is the flap $/ \mathrm{f} /$. Due to the fact that [l] is an allophone of $/ \mathrm{r} /$ in Korean, we can account for the tendency that Koreans associate Korean / $\mathrm{f} /$ with English /1/. As a result of the process described in (36), one can predict that Koreans would not have difficulty with English /1/ as long as it is in coda position of a syllable. Unfortunately, however, English itself has a phonological process that changes its /l/ into what's usually referred to as 'dark l' [ł]. This means that Koreans would have difficulty with English /1/ no matter where it appears: either in onset or in coda position. /1/ in coda position is difficult for Koreans since they would pronounce it as simple [1], although English /1/ in that position turns to dark 'l' [ł]. /l/ in onset position is difficult since Koreans tend to replace it with $/ \mathrm{r} /$ as shown below.

37) 'like,' 'love,' 'look' where the first consonant [1] is often pronounced with [r]

Sixth, Korean employs a voicing process where voiceless obstruents become voiced when occurring between voiced segments, most notably between vowels.

38) Voicing in Korean

/papo/ 'fool' $\rightarrow$ [pabo]

Accordingly, as this process is transferred into English, errors such as (39) are commonly observed.

39) Voicing transferred

$\begin{array}{llll}\text { 'walk in' } & / \mathrm{k} / & \rightarrow & {[\mathrm{g}]} \\ \text { 'look in' } & / \mathrm{k} / & \rightarrow & {[\mathrm{g}]} \\ \text { 'pick up' } & / \mathrm{k} / & \rightarrow & {[\mathrm{g}]}\end{array}$

Seventh, all fricatives and affricates in Korean, /t/ /th/ /t'/ /s/ / s'/ / $\mathrm{f} / / \mathrm{t} \int \mathrm{h} / / \mathrm{t} \mathrm{f}^{\prime} /$ are neutralized to [t] in coda position in Korean. Some examples are given in (40). 
40) Coda neutralization

$\begin{array}{llll}\text { pis } & \text { 'comb' } & \rightarrow & \text { [pit] } \\ \text { pit } \int & \text { 'debt' } & \rightarrow & \text { [pit] } \\ \text { pit } \int \mathrm{h} & \text { 'light' } & \rightarrow & \text { [pit] }\end{array}$

As a result of the transfer of the coda neutralization, we observe that Koreans have much greater difficulty with fricatives and affricates of English in coda position than in onset position. As we discussed above (see (25)), Koreans tend to replace fricatives and affricates with stops and/or add a default vowel to make them onsets.

\subsection{Failure to Acquire Phonological Processes}

In addition to the transfer of phonological processes from Korean to English, the failure to acquire phonological processes in English also leads to pronunciation errors. In this final section, let us briefly identify two such phonological processes in English.

One example of such phonological processes that are hard for Koreans to acquire is the process of aspiration. In English, there are no aspirated stops at phonemic level (see the chart in (16)). Voiceless stops /p, t, k/ become aspirated when they occur as the first segment of an onset (usually at a stressed position). See the contrast in (41).

41) Aspiration vs. non-aspiration

'star' [t]

'tar' $\quad\left[\mathrm{t}^{\mathrm{h}}\right]$

Due to the failure to acquire this process, Koreans tend to aspirate voiceless stops in English everywhere even when they are not in the relevant environment. Thus, the usual mistakes are observed in words like 'star' and 'stupid' where the ' $t$ ' sound is incorrectly pronounced as $\left[\mathrm{t}^{\mathrm{h}}\right]$.

Another example of phonological process in English that are not well acquired by Koreans is velarization of /1/. In English, /1/ becomes velarized (a dark 'l') in coda position. Observe the contrast in (42).

42) Velarization

'lie' [1]

'tell' [1]

The failure to acquire the velarization process in English results in errors where speakers of Korean end up pronouncing words such as 'tell' and 'sale' with a plain [1] rather than a velarized $[\nmid]$.

\section{Implications for Pedagogy}

Scholars and instructors of interpretation emphasize the importance of public speaking quality including pronunciation, accent, and intonation (Weber, 1984; Gile 1995). Based upon the reflection of the identified reasons of Korean students' English pronunciation mistakes in sections 3, 4 and 5, along with scholars' suggestions of teaching pronunciation (Trim, 1975; Doff, 1988; Celce-Murcia and Goodwin, 1991; Déjean Le Féal, 2003; Park, 2003), some helpful pedagogical tips are presented.

First, instructors should help students identify their mistakes. Instructors should assess needs of the class, groups, and individuals through questionnaires and listening 
tests. Production samples which record text reading and conversations with a native speaker can also be a useful tool for identifying mistakes. It is important for instructors to be more aware of their students' pronunciation needs in order to give a range of techniques.

Secondly, instructors should help students understand why such idiosyncratic pronunciation mistakes are made. Presentation of the comparative analysis of phonology and phonetics between Korean and English can be particularly beneficial to students of interpretation since they are advanced students of English.

Thirdly, instructors should develop a syllabus integrating pronunciation objectives into the overall syllabus and choose commercially made textbooks or make their own materials that will suit the students' needs.

Fourthly, instructors should help students drill in class through various techniques: 1) "listen and imitate/repeat" technique; 2) tongue-twisters such as "She sells sea shells by the seashore"; 3) minimal pair exercises such as lice-rice; 4) developmental approximation drill such as $/ \mathrm{W} / \rightarrow / \mathrm{I} /$ in wed $\rightarrow$ red; 5) drilling of vowel and stress shifts.

Fifthly, instructors should also give daily assignments to ensure sufficient practice including audiotaping given texts for self- and peer evaluation and teacher feedback. Regular visits to the language laboratory should also be encouraged.

Finally, instructors may assess students' ongoing progress frequently for identifying further needs, and priorities and also at the end of a training period, give final assessment by grading individual improvement along with accuracy of pronunciation.

With Donovan's (1998) argument in mind that there should be a clear distinction between language classroom and interpretation classroom in terms of correcting methodology, instructors and students of interpretation should collaborate in this effort. Then, there will be a remarkable improvement in students' interpretation quality including pronunciation.

\section{Conclusion}

The demands of the Korean interpretation market make it impossible for interpreters to avoid working into their B languages. As a matter of fact, many Korean interpreters of English confess that they are asked to interpret equally well into both Korean and English.

Interpretation training institutions in Korea make every effort to select qualified students and provide them with rigorous training in interpretation skills. It has been assumed that it is not the training institution's responsibility to help their students improve unrefined pronunciation of English and instructors or curriculum coordinators do not have to pay much attention to students' English pronunciation patterns and problems. Rather it is believed that perfecting students' English pronunciation is their own duty before or during their training. However, the reality proves that Korean students of interpretation still need to improve their English pronunciation for better speech delivery and interpretation quality.

As pointed out in this paper, there are patterns and problems in Korean students' English pronunciation due to the different phonetic/phonological structures and processes between Korean and English. Therefore, having a proper knowledge of these 
contrastive analyses of phonetic/phonological structures and processes and having a daily practice following the given tips will assist advanced students of English such as interpretation trainees in acquiring better speech delivery and interpretation quality including English pronunciation.

\section{NOTES}

1. The linguistic concept 'phonemic' is distinguished from 'phonetic' in that phonetic representations are surface realizations of phonemes, the mental representations of sounds. Thus, the phonemic inventory of a language includes only the basic sounds stored in the speakers' mind.

2. Among the variety of English dialects, here we choose to analyze one spoken most widely in North America, more specifically a southern Ontario Dialect.

3. Minimal pairs refer to two or more words that are identical except for one phoneme that occurs in the same position in each word, e.g., pain, bane, main.

4. We note that many dictionaries of English do not bother to transcribe these mid tense vowels with the off-glides but simply as /e/ and /o/. One could take this transcription practice as representing phonemes which automatically get realized as [ej] and [ow] at the phonetic level. However, for second language learners of English whose first languages do not have the diphthongized mid vowels, such a transcription practice possibly results in confusion if not sheer misunderstanding.

5. In fact, some dictionaries published in Korea use [i:] for the high front tense unrounded vowel and [i] for high front lax unrounded vowel. This symbolization obviously misleads students to think that the only difference between these two vowels is in length. Similarly misleading is the use of [u:] and $[\mathrm{u}]$, the former referring to the high back tense rounded vowel.

6. Children acquiring English go through a stage where the roundedness of $[\mathrm{I}]$ is picked up before they master the sound. As a result, they pronounce 'rabbit' as [wæbIt].

7. Note that the epenthesis shown in (32) does more than maintaining the maximal CVC structure in Korean. In fact, it makes CV structure by inserting another default vowel after the second consonant of the coda. This phenomenon suggests that the process of epenthesis is utilized not only to maintain the maximal syllable structure but perhaps the optimal syllable structure.

\section{REFERENCES}

AIIC Professional Standards (n.d.). Retrieved January 12, 2005 from <http://extranet.aiic.net/ AIIC> Basic Texts.

Burnaby, B. (1989): Parameters for Projects under the Settlement Language Training Programme, Toronto, Ontario.

Celce-Murcia, M. and J. Goodwin (1991): “Teaching Pronunciation,” In M. Celce-Murcia (ed.), Teaching English as a Second or Foreign Language, Boston, Heinle and Heinle Publishers.

Сног, J. (2004): “The Competitiveness of 'Into-B' Simultaneous Interpretation: A Correlation Based on Age," Forum 2-2, p. 271-292.

Déjean Le FÉAL, K. (1999): “The European Masters in Conference Interpreting," Conference Interpretation and Translation 1, p. 39-45.

Déjean Le Féal, K. (2003): "Impact of the International Status of the Interpreting Student's Mother Tongues on Training," Forum 1-1, p. 63-76.

Doff, A. (1988): Teach English: A training course for teachers, Cambridge, Cambridge University Press.

Donovan, C. (1998): “Teaching Expression in Interpretation," In F. Israel (ed.), Quelle formation pour le traducteur de l'An 2000? Actes du Colloque International tenu a l'ESIT les 6, 7 et 8 juin 1996, Paris, Didier Erudition.

GiLe, D. (1995): Basic Concepts and Models for Conference Interpretation Training, Amsterdam/ Philadelphia, John Benjamins.

Kondo, M. (2003): 3-Party 2-Language Model of Interpreting Revisited, Forum 1-1, p. 77-96.

Kurz, I. (1994): “What Do Different User Groups Expect from a Conference Interpreter?, The Jerome Quarterly 9-2, p. 3-7. 
LAdo, R. (1957): Linguistics Across Cultures: Applied Linguistics for Language Teachers, Ann Arbor, Michigan, University of Michigan.

LI, D. (2002): “Translator Training: What Translation Students have to Say," Meta 47-4, p. $513-$ 531.

Lim, H.O. (2003): “Interpreting into B: To B or not to B?,” Forum 1-2, p. 151-171.

Minns, P. (2002): "The Teaching of Interpreting into B - Some Conclusions Gathered from 25 Years' Training Experience," Conference Interpretation and Translation 4-2, p. 29-40.

NG, B. C. (1992): "End Users' Subjective Reaction to the Performance of Student Interpreters," The Interpreters' Newsletter Special Issue 1, p. 35-41.

O'Grady, W. and J. Archibald (2004): An Introduction: Contemporary Linguistic Analysis, Toronto, Pearson Longman.

PARK, H. K. (1999): "A Study on Developing an Interpretation Track for Undergraduate Students," Conference Interpretation and Translation 1, p. 47-74.

PARK, H. K. (2003): “The Korean Speech Training in Teaching Interpretation," Conference Interpretation and Translation 5-1, p. 125-144.

PArK, H. K. (2004): "Applying Second Language Acquisition Theories to Teaching Interpretation to Undergraduate Students," Forum 2-1, p. 105-123.

Seleskovitch, D. (1999): "The Teaching of Conference Interpretation in the Course of the Last 50 Years," Interpreting 4-1, p. 55-66.

Seleskovitch, D. and M. Lederer (1989): A Systematic Approach to Teaching Interpretation, Luxembourg, Didier Erudition.

Shlesinger, M. (1994): "Intonation in the Production and Perception of Simultaneous Interpretation," In S. LAmbert and B. Moser-Mercer (eds.), Bridging the Gap: Empirical Research in Simultaneous Interpretation, Amsterdam and Philadelphia, John Benjamins, p. 225-236.

Trim, J. (1975): English Pronunciation Illustrated, Cambridge University Press.

Wardhaugh, R. (1970): “The Contrastive Analysis Hypothesis," TESOL Quarterly 4, p. 123-30.

WeBER, W. (1984): Training Translators and Conference Interpreters. Language in Education: Theory and Practice 58, New York, Prentice-Hall. 